\title{
Changing Tourism Consumer Behavior: The Impacts on Tourism Demand in Albania
}

\author{
Irisi Kasapi, Macit Koc
}

\section{Abstract}

Purpose of the article Exploring the nature of tourism behavior has traditionally been very complex. Adding to it the fast pace changing environment, the study becomes even more complicated. The purpose of this research is to shed light on the relationship between factors affecting tourist behavior and tourism demand in Albania.

Methodology/methods Tourism demand has generally been measured in terms of 'number of people entering and exiting the borders of a country'. In order to ensure the feasibility of this study, 'tourism demand' is measured in terms of 'frequency of travels'. To accomplish these objective, an online survey questionnaire was developed and administered across the population of Tirana and Durres, the largest cities in Albania, which also represented the population $(N)$ upon which the sample size was drawn. Scientific aim Scientifically, the research aims at testing the relationship between the sample's monthly income levels, denoted as the independent variable and 'frequency of travel', denoted as the dependent variable. Findings The results of the research show that there is a significant association between these two constructs. That is, with $\boldsymbol{x}^{2}(1, N=133)=\mathbf{1 0 2 , 5 8 1}, \boldsymbol{p}=\mathbf{. 0 0 0}<0.01$, the Null Hypothesis is rejected, and the Alternative Hypothesis is accepted. Conclusions From the study it is concluded that the higher the Monthly Income levels of the Albanian tourists, the higher the frequency of travels. Nevertheless, like in every other study there are also limitations involved with this particular study, as well. The lack of reliable quantitative data concerning the Albanian domestic tourism is one among the most crucial ones.

Keywords: $\quad$ Tourist Behavior, Tourism Demand, Determinants of Tourism Demand, Frequency of Travel.

JEL Classification: M30, M39

\section{Introduction}

Living in a world where the only constant is change, understanding, to then predicting consumer behavior has become a focal point to the large body of researchers, 
and tourism marketers. In this respect, it is crucial to be able to understand the individuals' behavior, around which revolves everything; how the tourism consumer thinks and decides about the consumption of tourism products, which in turn affects the demand for tourism. Tourism in our days is increasingly being considered more as a social phenomenon. Further, the nature of the society has shifted from that of a traditional economy focused on production to that focused on providing mostly service related products (Page, 2009, p.10). Over time, and especially during the post-war era, the labor started to experience an increase in the "leisure time and paid holiday entitlement”; in this way they had more possibilities to engage in different types of consumption, such as tourism.

According to Dr. Wieslaw Bogdan Alejziak, professor at the Institute of Tourism and Recreation at Academy of Physical Education in Kraków, "Some of the more visible processes in our modern life include; the quick development of the technology, the revolution in genetics, the conquest of outerspace, the rapid development of cities, and the changes in our jobs and lifestyles" (Alejzik, W. B., 2002a). In this context, it is being argued that there is going to be a shift from the traditional industries to the industries built upon modern technology, generating in this way radical transformations in "the relationships of our home and work place, working time and free time, and prosperity versus poverty" (Alejzik, W. B., 2002b). Being testimonials of this fast-pace changing environment, it is necessary to explore and study the tourist, being that he is the most essential ingredient of tourism demand. As a matter of fact, there are a bundle of researches and studies in the field of tourism in Albania, but just a few of them attempt to account for changes in tourism consumer behavior.

Robert Nesbit (as cited in Crompton, 1979a, p. 408) distinguishes four different subdivisions in the travel market, "personal business travel, government or corporate business travel, visiting friends and relatives, and pleasure vacation travel”. This study will be concentrating mostly on the latter. In other words, this study investigates the impact of Albanian people monthly income level as an influential determinant of tourism demand on tendency to travel.

\section{Literature Review}

\subsection{Definitions}

Before one can study tourist behavior and its impact on tourism demand, it is important to reach into some agreement as to what is meant by a few of the most widely cited terms in the tourism research field. Nevertheless, defining tourism and tourism-related terms is a far from easy task.

Various attempts have been made by large organizations and individual researchers to continuously improve and further narrow the definitions of these key terms. As such, according to the World Tourism Organization (WTO), tourism is defined as the "social, cultural and economic phenomenon which entails the movement of people to countries or places outside their usual environment for personal or business/professional purposes” (UNWTO, 2012, para. 1). The definition of 'tourism' has however created high waves of debate among researchers of this field, who have continuously attempted to point to the differences between a 'visitor' and a 'tourist', 'domestic tourists' and 'international tourists', 'tourism' and 'travel', and many other constructs of this type (Page, 2009, p. 15). 
Two other major concepts worth defining prior to starting this journey through the study are 'tourist consumer behavior' and 'tourism demand'. Because what is being studied is the demand side of tourism, it is essential to get an understanding of what its main component, the tourist, is, and what drives their tendency to demand tourism products. Tourist behavior has traditionally been viewed as a complex area of research; as such different definitions are derived from the fundamental topic of consumer behavior, in order to construct that of tourist behavior. Researchers have differently defined consumer behavior in tourism.

John Swarbrooke and Susan Horner, in their account 'Consumer Behavior in Tourism', have provided the following definition, "Consumer behavior is the study of why people buy the product they do, and how they make their decision”. Another definition adapted for tourism consumer behavior, is the one developed by Michael R. Solomon, Ph.D., Professor of Marketing and Director of the Center for Consumer Research, who incorporates the concepts of needs and wants into his definition, "Consumer behavior is the process involved when individuals or groups select, purchase, use or dispose of products, services, ideas or experiences to satisfy needs and wants" (as cited in Swarbrooke \& Horner, 2007a, p. 6). Janet McColl-Kennedy, professor of Marketing and Director of Research in Business, on the other hand, defines tourist behavior as "the actions a person takes towards purchasing and using products and services, including the decision-making process that precedes and determines the actions” (as cited in Gulid, Lertwannawit, Saengchan, 2010, p. 645).

Getting back to tourism demand, various definitions have been developed in this respect, as well. Nevertheless, two are the main definitions that will lead this study. One of them is proposed by Douglas Pearce, professor of Tourism Management, according to whom tourism demand is "the relationship between individuals' motivation [to travel] and their ability to do so" (as cited in Page, 2009a p. 84). In contrast, a more economic-oriented definition is proposed by Chris Cooper. According to the Marketing professor with an outstanding career in T-research and T- education, tourism demand is "the schedule of the amount of any product or service which people are willing and able to buy at each specific price in a set of possible prices during specified period of time" (Cooper, Fletcher, Gilbert, Wanhill, 1993).

\subsection{Consumer Behavior Models in Tourism}

Generally speaking, the main aim of the Consumer Behavior models is to provide a simplistic picture of the factors that drive consumers' buying decision making process (Swarbrooke \& Horner, 2007b, p. 40). Seaton (1994) recognizes the intangible nature of tourism services as being the crucial reason explaining why special attention should be paid on the tourist' decision making process. Because tourists have to decide about a relatively high-spending activity such as tourism, considering also that they only have in their own imagination how their holiday will be, a high-risk decision making process is inevitably involved from their part. For this reason, the tourist will spend relatively more time on his or her decision making about purchasing tourism products and will as a consequence be more involved in the purchase decision. Considering also that large amounts are committed for something you cannot see, leaves the tourist with an opportunity cost of disastrous holiday being uncorrectable. 
Figure 1: Andreasen model of Consumer Behavior

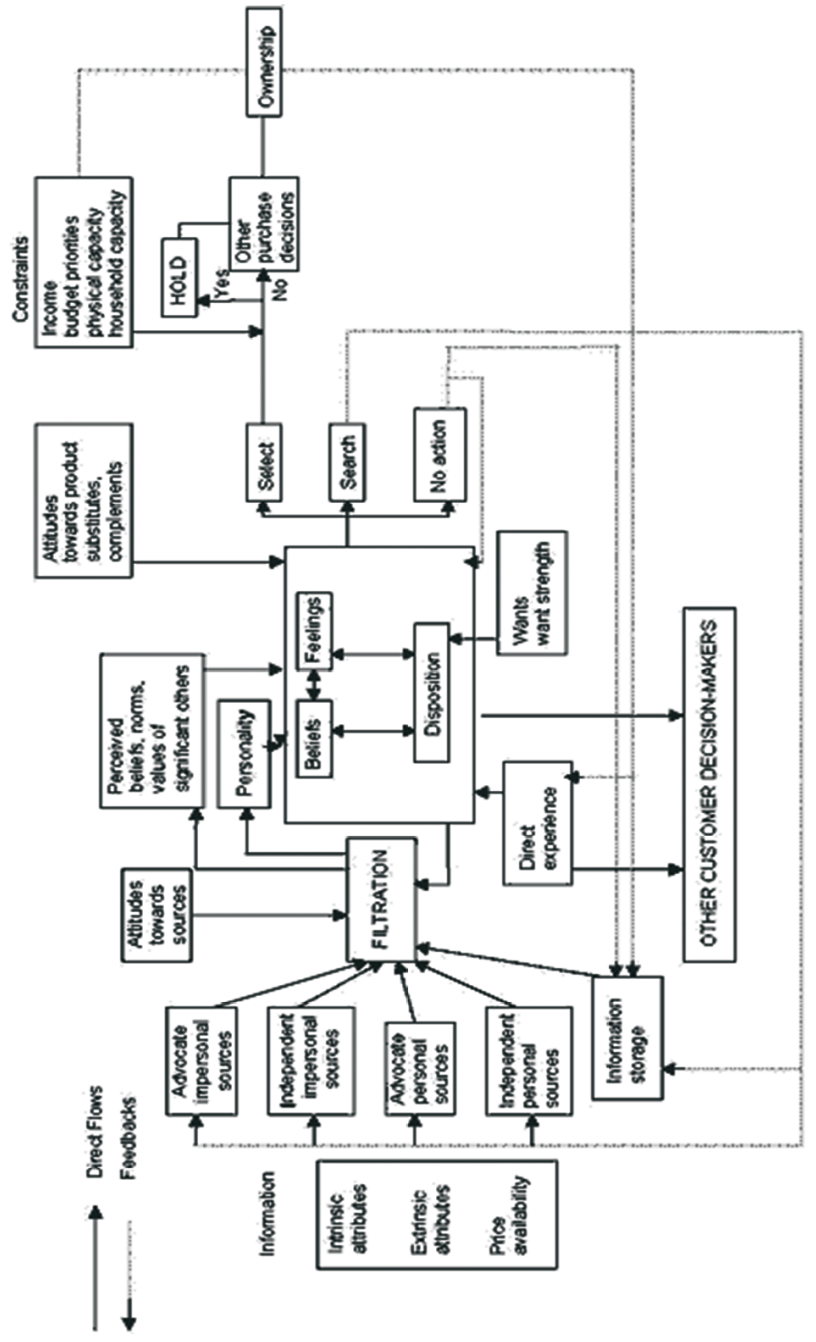

Source: (Andreasen, 1965)

One among the earliest models of consumer behavior was proposed by Andreasen back in the 60's. Information was the essential focus of this model, considering it as the most important ingredient in the consumers' decision-making process (as cited in Swarbrooke \& Horner, 2007, p. 40). This model is displayed in Figure 1. While it successfully considers the significance of 'attitudes', it lacks acknowledging attitudes when it comes to purchase behavior reiteration (Andreasen, 1965).

In a like manner, Nicosia (as cited in Swarbrooke \& Horner, 2007) proposed the model shown in Figure 2. According to this model, the overall consumer decision making process, together with the firms' communication process with the consumer, is separated into four fields. The first field includes the firm's attempts to communicate with the consumers and the consumer's inclination to behave in a certain manner. The second field involves the consumer's search evaluation; the third one represents that act of purchase 
accompanied by the consumer's purchasing behavior, whereas the last field involves the consumer's post-purchase behavior and feedback (Swarbrooke \& Horner, 2007).

\section{Figure 2: Nicosia model of Consumer Behavior}

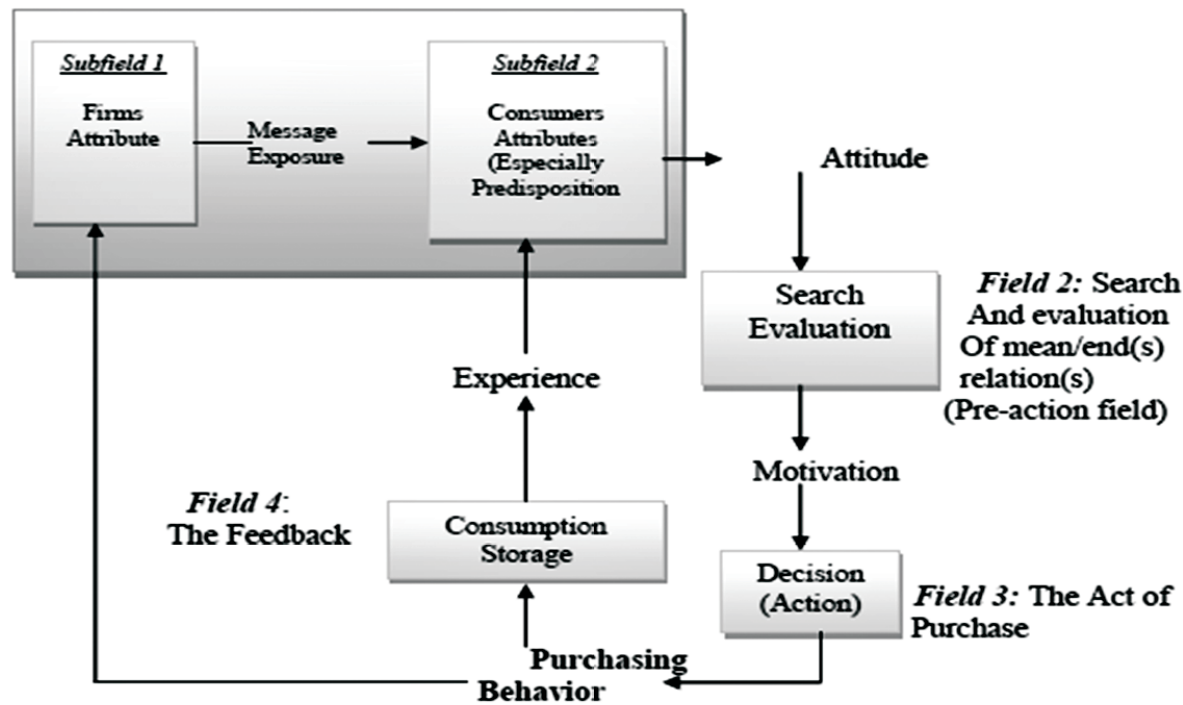

Source: (Swarbrooke \& Horner, 2007f, p.42)

Furthermore, another very well-known representative theory of the buyer behavior is embedded in the Howard-Sheth model, shown in Figure 3. This model is very complex in nature and is focused on four different variable sets, specifically: "stimulus variables, response variables, hypothetical constructs and exogenous variables" (Howard \& Sheth, 1969a, p. 470). As it may be observed, at the central part of the model lies a rectangular box containing several internal variables, which in turn describe the overall state and condition of the buyer. According to John A. Howard and Jagdish N. Sheth, founders of this model, the hypothetical constructs play the role of endogenous variables meaning that their changes can be given a reason for (Howard \& Sheth, 1969b). In this respect, they have classified them in two different groups "learning constructs and perceptual constructs”. The first notion includes seven variables, namely specific and nonspecific motives, brand potential, decision mediators, predisposition toward brands, inhibitors and satisfaction with the brand purchase. The learning constructs basically point at the buyer's process of opinion and beliefs formation until the final purchase decision is taken.

The second construct, on the other hand, deals with how the consumer acquires and processes information taken from the input variables, in order to make his purchase decision. Three are the main perceptual constructs that this model employees, shown also in Figure 3-3, "sensitivity to information, perceptual bias, and search for information” (Howard \& Sheth, 1969c, p.477).

An equally very important part of the model is the inputs to this big rectangular box, or put in another way the stimuli that affect the buyer's internal condition. This stimulus comes from the marketing and social environment, and range from quality, price distinctiveness, availability and service of the brands to the social influencers such as family, reference groups and social class (Howard \& Sheth, 1969d, p. 470). The outputs, on the other hand, represent the various responses that the buyer will most probably 
disclose as a result of the communication between stimuli and his internal condition (Howard \& Sheth, 1969e). In addition to the inputs, there is also an array of "influences" to the rectangular box, or namely to the hypothetical constructs or the internal state of the buyer. There are seven of them listed at the top of the model, and are marked as "exogenous" variables. Importance of purchase, personality variables, social class, culture, organization, time pressure and financial structure according to the authors "are several influences operating on the buyer's decisions which we treat as exogenous: that, is we do not explain their formation and change" (Howard \& Sheth, 1969f, p. 485).

\section{Figure 3: Howard-Sheth Model of the Theory of Buyer Behavior}

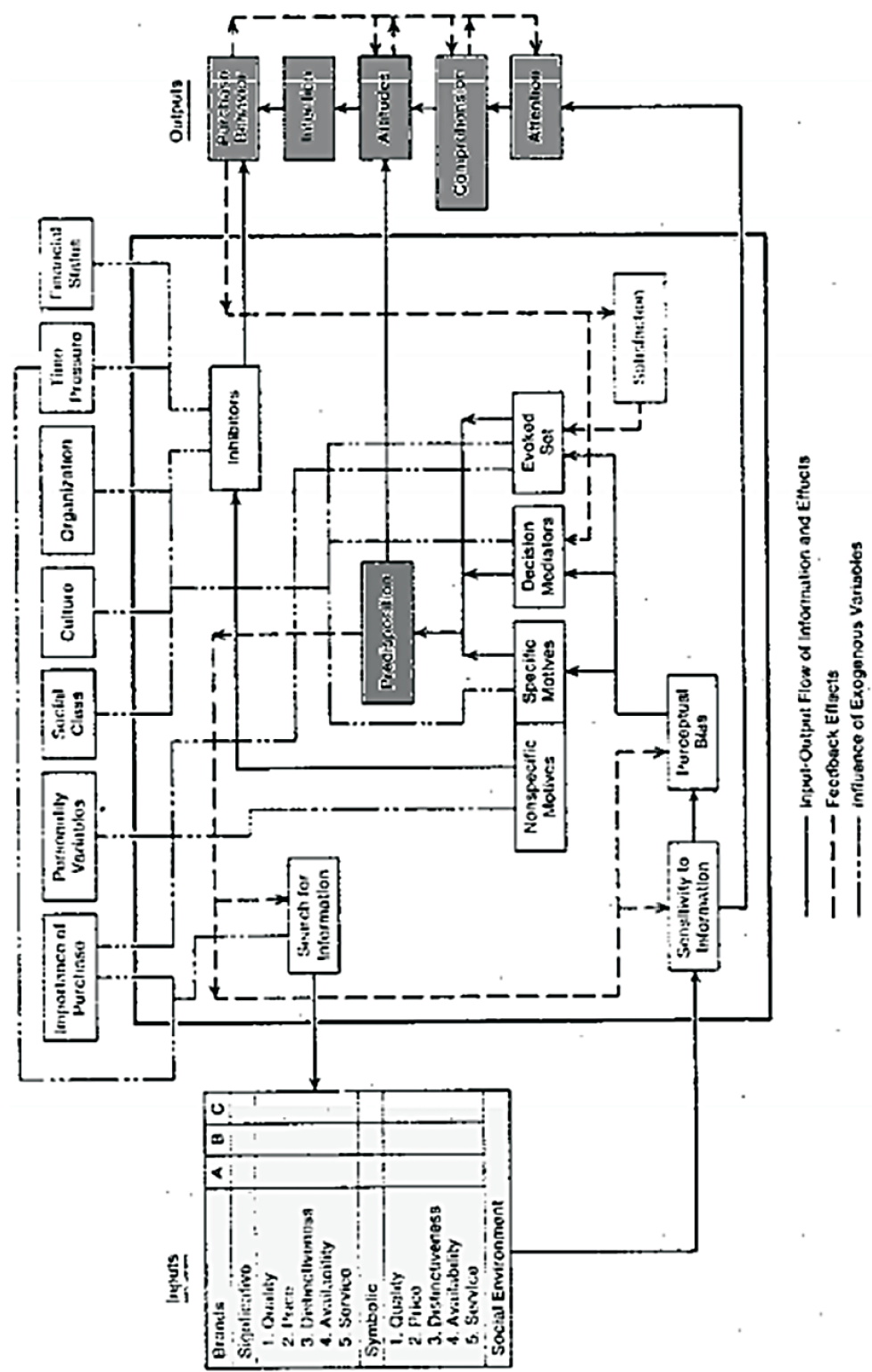

Source: (Howard \& Sheth, 1969g) 
Lastly, Mathieson and Wall (as cited on Wall \& Mathieson, 2006a) brought about a more simplistic version of the buyer behavior, this time adapted for tourism consumers. Figure 4 displays a diagram of the model, which is mostly linear in nature. The model is in essence aligned to the general five steps employed during consumer's decision making process, but adapted specifically to the tourism product, ranging from felt need to travel (or need recognition) to travel satisfaction outcome (or post-purchase evaluation).

\section{Figure 4: Travel-buying Behavior}

\begin{tabular}{|c|c|c|c|c|}
\hline $\begin{array}{c}\text { Felt need/ } \\
\text { travel } \\
\text { desire }\end{array}$ & $\begin{array}{l}\text { Information } \\
\text { collection } \\
\text { and } \\
\text { evaluation } \\
\text { image }\end{array}$ & $\begin{array}{c}\text { Travel } \\
\text { decision } \\
\text { (choice } \\
\text { between } \\
\text { alternatives) }\end{array}$ & $\begin{array}{c}\text { Travel } \\
\text { preparation } \\
\text { and travel } \\
\text { experiences }\end{array}$ & $\begin{array}{c}\text { Travel } \\
\text { satisfaction } \\
\text { outcome and } \\
\text { evaluation }\end{array}$ \\
\hline
\end{tabular}

Source: (adapted from Mathieson and Wall 1982; as cited in Wall \& Mathesion 2006b)

Having traveled through the various general consumer behavior models, we have observed that most of the consumer behavior models in tourism are overly simplified if compared to the broad consumer behavior models (Wall \& Mathieson, 2006c). This does not mean, however, that consumer behavior in tourism is a simple process in itself. On the contrary, because tourism involves various features, consumer behavior in tourism is highly complex in nature. In this respect, Swarbrooke and Horner in their account 'Consumer Behavior in Tourism' claim that "the diverse characteristics of tourism mean that consumer behavior in tourism will inevitably be very complex" (Swarbrooke and Horner, 2007g, p. 47).

\section{Conceptual Frameworks and Hypothesis}

\subsection{Research Question}

The primary objective of this study is to answer to its main question:

Q.1: What is the relationship between the determinants of the Albanian tourist's demand and tendency to travel?

\subsection{Hypothesis}

Theory indicates that the factors that influence consumer's buying behavior are divided into motivators and determinants (Swarbrooke and Horner, 2007h). The studies on holiday motivation are rather large and complex, and as such in order to provide a thorough and meaningful research it needs to be addressed in a separate study. It has been generally accepted in the literature of econometric models of tourism demand that tourist's personal Income level influences their overall buying behavior and as a consequence their willingness to purchase tourism products. Based on various scholars' theory arguments for the scope of this intended study, the following hypothesis is constructed to then be tested, using data from Albanian tourism consumers.

$\mathrm{H}_{0}$ : Monthly Income levels of Albanian tourists and tendency to travel (measured in terms of frequency of travel) are statistically independent. 
$\mathrm{H}_{1}$ : The higher the Monthly Income levels of Albanian tourists, the higher the tendency to travel (measured in terms of frequency of travel).

\section{Research Design}

\subsection{Methodology}

In realizing this study, a combination of primary and secondary sources was adopted. Looking at the bigger picture, this study is considered to be part of what are called intentional studies, and more specifically it is a pre-travel study on the Albanian tourist's intended travel preferences, habits and patterns. In addition, from the objectives perspective, overall the research attempts to discover the relationship between monthly income (as a determinant of tourism demand) and tendency to travel (measured in terms of frequency of travel). In this respect, this research can be considered a correlation research.

\subsubsection{Justification for the Methodology Used}

In choosing this methodology, it was considered the fact that a relatively large and well structured survey was employed as an information gathering technique. For this reason it was thought that a research with the above characteristics would have been more appropriate, if compared to other types of research such as qualitative and observational ones.

\subsection{Population and Sample Size}

The study was carried out in Albania. Because random sampling is used to select the sample size, in principle every individual within the two major cities in Albania, Durres and Tirana have an equal chance of being selected, because once again in principle everyone engages in tourism activities, and the selection is completely based on chance. Knowing from secondary sources that the population of Tirana and Durres is 374,801 and 122,034 respectively, we say that our population $(\mathrm{N})$ to be studied is 496,835 Albanian consumers (Central Intelligence Unit, 2012). However, it is worth mentioning that in this case because population size is by common knowledge and understanding large and not well defined (because tourism consumer is being studied), the population size does not represent a big concern. However attempts are made to clarify the margin of error or confidence interval for the sample size of this study. As a matter of fact, the amount of error to be tolerated, considering a sample size $(n=141)$, a response distribution of $50 \%$ and a confidence level of $95 \%$ (representing the amount of uncertainty to be tolerated), is that of + + $8.3 \%$.

\subsection{Questionnaire Design}

The questionnaire is designed as an online survey instrument to collect data on the sample of interest, attempting to shed light on the hypothesis constructed. It is composed of 25 items that have been extracted from a review of the various literatures. More specifically, the survey is composed of 6 demographic questions, which include items such as gender, age, occupation, monthly income, education level, and the respondent's self-description as a tourist. In addition, two other items are employed to understand the consumer's motivation to travel with 13 attributes extracted from prior studies 
(Crompton, 1979; Page, 2009b). The next 16 items measure the determinants of tourism consumer buying behavior (Swarbrooke and Horner, 2007ch; Uysal, 1998). Finally, the survey contains one dependent variable which measures tendency to travel of the average Albanian tourist in terms of frequency of travel, the relationship of which will be further tested against the independent variables.

The online survey was left out for a collection period of one month, from April $29^{\text {th }}$ until May 30 ${ }^{\text {th }}$ 2012, and 141 responses were collected as a consequence.

\subsubsection{Data Analysis}

When it comes to the method chosen to analyze the data gathered from the survey, a quantitative method has been employed. The data is processed though SPSS 20.0, the most commonly used statistical package. Data analysis includes various statistical tools such as factor analysis, and chi-square testing, for which will be talking in more details during the presentation of the results.

As far as the answers attained from the questionnaire is concerned, they were measured based on three different types of scales: nominal, ratio, ordinal (likert) scale. Facing time constraints, on the other hand, In order to get back responses in the shortest possible amount of time, they were sent by e-mail. As such, the questionnaires were distributed by e-mail in the form of a Web link and the responses were directly received on the survey's online platform ${ }^{1}$. Once the collection phase has terminated on May $30^{\text {th }}$, the data was directly exported to the SPSS 20.0 software, removing in this way any incorrectness accompanying the data entering process.

\section{Respondent's Demographic Profile}

The respondents' demographic profile is depicted based on six different dimensions. The first characteristic is gender. The gender composition of the respondents is $34 \%$ male and $66 \%$ female, showing a significant difference between them when it comes to the participation on the survey. Results from the age variable, on the other hand, indicate that the majority of the respondents, around $57 \%$ of them belong to the age group 21 to 31 years old. As such, the second most populated age group of the respondents is that from 20 years old and under, accounting for $14 \%$ of the responses.

Furthermore, about 50\% of them had a Bachelor Degree as their highest level of education, $1.4 \%$ had a $\mathrm{PhD}$ (about 2 persons out of 141 who actually responded to this question), and none of them had less than a high school degree, providing us with good reasons to suspect that the we have to deal with well educated and sophisticated consumers.

When it comes to the occupation of the respondents, about $40 \%$ of them are students, $21 \%$ are in the Professional/Technical category, while the other ones populate the other categories. This relatively large percentage of student participant is mainly due to the fact that the survey was distributed online.

Because of its intangible nature, the purchase of a tourism product involves a complex decision making process, a process which sometimes because of the lack of resources (time, money etc.,) results into what is known as 'suppressed' demand, or even

1) The online platform used to design the survey and then launch it for data gathering is called Survey Monkey 
into 'no demand' at all (Page, 2009b). For this reason it is being closely considered the respondent's monthly income level, as an important indicator of the consumer's purchasing power. As it can be seen on Table $\mathbf{1}$ below, around 31\% of the respondents have a monthly income of from ALL20, 000 to ALL 40,000, while 30\% of them populate the second category, from ALL41, 000 to ALL60, 000.

The final characteristic for which the sample under study was asked about was a set of items based on which they would have to classify themselves as tourists. On a gender perspective, around $26 \%$ of females describe themselves as 'Single Income, No Kids' tourists, while $52.1 \%$ of males describe themselves as 'Backpackers'.

Table 1: Socio-Demographic Characteristics of the Respondents

\begin{tabular}{|c|c|c|c|}
\hline Variables & Categories & $\begin{array}{l}\text { Frequency } \\
(n=141)\end{array}$ & $\begin{array}{l}\text { Valid Percent } \\
\qquad(n=100 \%)\end{array}$ \\
\hline \multirow[t]{3}{*}{ Gender } & Female & 93 & $66,0 \%$ \\
\hline & Male & 48 & $34,0 \%$ \\
\hline & Total & 141 & 100 \\
\hline \multirow[t]{7}{*}{ Age } & 20 and Under & 20 & $14,2 \%$ \\
\hline & $21-30$ & 81 & $57,4 \%$ \\
\hline & $31-40$ & 14 & $9,9 \%$ \\
\hline & $41-50$ & 12 & $8,5 \%$ \\
\hline & $51-60$ & 10 & $7,1 \%$ \\
\hline & 60 and Over & 4 & $2,8 \%$ \\
\hline & Total & 141 & $100 \%$ \\
\hline \multirow[t]{6}{*}{ Degree } & High school degree or equivalent & 13 & $9,2 \%$ \\
\hline & 3-years college & 19 & $13,5 \%$ \\
\hline & Bachelor degree ( 4 years) & 71 & $50,4 \%$ \\
\hline & Masters degree & 36 & $25,5 \%$ \\
\hline & PhD. degree & 2 & $1,4 \%$ \\
\hline & Total & 141 & $100 \%$ \\
\hline \multirow[t]{10}{*}{ Occupation } & Professional/Technical & 30 & $21,3 \%$ \\
\hline & Executive Administrator & 7 & $5,0 \%$ \\
\hline & Middle Management & 14 & $9,9 \%$ \\
\hline & Sales/Marketing & 14 & $9,9 \%$ \\
\hline & Self-employed/Business Owner & 6 & $4,3 \%$ \\
\hline & Clerical or Service & 5 & $3,5 \%$ \\
\hline & Student & 56 & $39,7 \%$ \\
\hline & Unemployed & 6 & $4,3 \%$ \\
\hline & Retired & 3 & $2,1 \%$ \\
\hline & Total & 141 & $100,0 \%$ \\
\hline \multicolumn{2}{|l|}{ Valid } & 131 & $92,9 \%$ \\
\hline
\end{tabular}




\begin{tabular}{|c|c|c|c|}
\hline Variables & Categories & $\begin{array}{l}\text { Frequency } \\
(n=141)\end{array}$ & $\begin{array}{l}\text { Valid Percent } \\
\qquad(n=100 \%)\end{array}$ \\
\hline & Asst. Specialist & 1 & $0,7 \%$ \\
\hline & Auditor & 1 & $0,7 \%$ \\
\hline & Banker (Credit Officer) & 1 & $0,7 \%$ \\
\hline & History Teacher & 1 & $0,7 \%$ \\
\hline & Lawyer / Internal Audit & 1 & $0,7 \%$ \\
\hline & specialist, banking & 1 & $0,7 \%$ \\
\hline & Teacher & 3 & $2,1 \%$ \\
\hline & Total & 141 & $100 \%$ \\
\hline \multirow{8}{*}{$\begin{array}{l}\text { Monthly } \\
\text { Income }\end{array}$} & ALL20000-40000 & 44 & $31,20 \%$ \\
\hline & $41000-60000$ & 43 & $30,50 \%$ \\
\hline & 61000-80000 & 24 & $17,00 \%$ \\
\hline & $81000-100000$ & 12 & $8,50 \%$ \\
\hline & $110000-200000$ & 7 & $5,00 \%$ \\
\hline & $200000-500000$ & 10 & $7,10 \%$ \\
\hline & over 500000 & 1 & $0,70 \%$ \\
\hline & Total & 141 & $100 \%$ \\
\hline \multirow{8}{*}{$\begin{array}{l}\text { Tourist } \\
\text { Self-Descrip } \\
\text { tion }\end{array}$} & Backpackers & 55 & $39,30 \%$ \\
\hline & Empty Nesters & 11 & $7,90 \%$ \\
\hline & DINKS & 15 & $10,70 \%$ \\
\hline & SINKS & 33 & $23,60 \%$ \\
\hline & Double. Kids & 22 & $15,70 \%$ \\
\hline & Early/Active Retirees & 2 & $1,40 \%$ \\
\hline & Youth & 2 & $1,40 \%$ \\
\hline & Total & 140 & $100 \%$ \\
\hline Missing & System & 1 & \\
\hline
\end{tabular}

\section{Empirical Results}

\subsection{Reliability and Factor Analysis}

Reliability and Validity (Bryman, 2008) are two very important building blocks upon which the quality of a research is based. While reliability is defined as "the extent to which a questionnaire, test, observation or any measurement procedures produces the same results on repeated trials" (Miller, n.d), validity is considered to be "the extent to which the instrument measures what it purports to measure".

Having these very important theoretical concepts in mind, this pre-hypothesis testing phase of the thesis will serve to assess one of the aspects of reliability2) for the variables

2) There are three aspects of reliability, namely: equivalence, stability and internal consistency (homogeneity) (Miller, n.d). 
employed in a research, that of internal consistency. The primary objective of conducting a factor analysis in this study is to funnel the determinants of tourism demand in Albania (variables that measure them) into the respective component that best describes each, or more simply, to group together items with similar characteristics. Before conducting a factor analysis, however, a reliability test is carried out, to see whether a factor analysis is reliable and meaningful to be conducted.

From the scale reliability analysis, it was found out that the content validity of the survey instrument is adequate and acceptable. A Cronbach $\alpha$ of 0.73 indicates an acceptable level of reliability between the scores of the survey data. In the social sciences and especially when conducting basic research the benchmark for the reliability is 0.70 or better (Cronbach, 1951, as cited in Grau, n.d., p.3104). Table 2 summarizes the result. In this respect it can be concluded that this indicator is high enough for us to conduct a reliable and meaningful factor analysis that will generate several components among the sets of items within the questionnaire.

Table 2: Scale Reliability Statistics

\begin{tabular}{|c|c|c|}
\hline \multicolumn{3}{|c|}{ Reliability Statistics } \\
\hline Cronbach's Alpha & $\begin{array}{c}\text { Cronbach's Alpha Based on } \\
\text { Standardized Items }\end{array}$ & No. of Items \\
\hline, 730 &, 712 & 9 \\
\hline
\end{tabular}

Moreover, a Kaiser-Meyer-Oklin measure of sampling adequacy of 0.75 and a significance of .000 are indications that a meaningful factor analysis may be conducted. Table 3 summarizes the results.

Table 3: KMO Measure of Sampling adequacy and Bartlett's Test

\begin{tabular}{|l|l|c|}
\hline \multicolumn{2}{|c|}{ KMO \& Barlett's Test } \\
\hline Kaiser-Meyer-Olkin Measure of Sampling Adequacy. &, $\mathbf{7 2 5}$ \\
\hline \multirow{3}{*}{ Bartlett's Test of Sphericity } & Approx. Chi-Square & 237,264 \\
\cline { 2 - 3 } & df & 36 \\
\cline { 2 - 3 } & Sig. & $\mathbf{0 0 0}$ \\
\hline
\end{tabular}

As mentioned earlier, the determinants of tourism consumer buying behavior are measured using a 9-items scale. By employing the principal components factor analysis, four factors with an eigenvalue greater than one explained $69.139 \%$ of the variance of determinants of tourism consumer behavior. Moreover, 5 variables with factor loading less than 0.5 were removed.

Equally, if we take a look at our descriptive statistics on these variables (Table 4), it can be easily observed from the item's means that 'Social Networks', such as Facebook and Twitter are overall the most important variable that influences Albanian tourist to buy tourism products. It has the highest mean among all other variables, 3.1926. 
Table 4: Descriptive Statistics

\begin{tabular}{|l|c|c|c|}
\hline \multicolumn{4}{|c|}{ Descriptive Statistics } \\
\hline & Mean & Std. Deviation & Analysis N \\
\hline Personal_Experience & 1,6815 & 0,7693 & 135 \\
\hline Friends_Colleagues & 2,2741 & 0,90956 & 135 \\
\hline Guidebooks and Magazines & 3,0593 & 1,07733 & 135 \\
\hline Official websites of the hotels \& destinations & 2,4667 & 1,16414 & 135 \\
\hline Social Network (Facebook, Twitter, etc) & 3,1926 & 1,15575 & 135 \\
\hline TravelTour_Operators & 2,3704 & 1,15086 & 135 \\
\hline Media & 3,1185 & 1,09988 & 135 \\
\hline Information_Technology & 2,9481 & 1,03893 & 135 \\
\hline Tour_Operators & 2,5556 & 0,85227 & 135 \\
\hline
\end{tabular}

Table 5 summarizes the results of the loadings of the nine variables on the four components identified. As it can be understood by the factor loadings of each of the variables, the first factor includes items such as, 'Guidebooks and Magazines', 'Official Websites of the Hotels and Destinations', 'Social Networks', 'Travel and Tour Operators' and 'Media'. The high values of the factor loadings in the first component tell that these variables are the ones which take the most attention for the respondents during their decision making process. Within this factor, however, the variables with the highest loading are 'Guidebooks and Magazines' (0.709) and 'Social Networks' (0.709). This clearly shows that for Albanian tourists' the power of social media in influencing their tourism product purchases is considerably higher if compared to the traditional marketing channels.

'Information Technology', on the other hand, has a higher factor loading on the second component. A high factor loading (0.727) on this item tells us that the respondents consider it as a very important determinant for the decision making process when it comes to buying tourism products. The third component (factor) displays high loadings on the 'Friends \& Colleagues' and 'Tour Operators' items, 0.676 and 0.517 respectively. And last, the 'Personal Experience' item is highly loaded (0.915) on factor 4.

Overall, it can be concluded that, based on the factor loadings of each of the items, 'Guidebooks and Magazines', 'Social Networks', 'Information Technology' and 'Personal Experience' are the determinants of tourism demand which influence the most the Albanian tourist's decision making process.

Table 5: Component (Factor) Matrix showing the loadings of the nine variables on the four factors extracted

\begin{tabular}{|l|c|c|c|c|}
\hline \multicolumn{5}{|c|}{ Component Matrix $^{\mathrm{a}}$} \\
\hline & \multicolumn{4}{|c|}{ Component } \\
\cline { 2 - 5 } & $\mathbf{1}$ & $\mathbf{2}$ & $\mathbf{3}$ & $\mathbf{4}$ \\
\hline Personal_Experience & 0,224 & 0,012 & 0,161 & $\mathbf{0 , 9 1 5}$ \\
\hline Friends_Colleagues & 0,388 & $-0,014$ & $\mathbf{0 , 6 7 6}$ & $-0,315$ \\
\hline
\end{tabular}




\begin{tabular}{|l|c|c|c|c|}
\hline \multicolumn{4}{|c|}{ Component Matrix ${ }^{\mathrm{a}}$} \\
\hline & \multicolumn{4}{|c|}{ Component } \\
\cline { 2 - 5 } & $\mathbf{1}$ & $\mathbf{2}$ & $\mathbf{3}$ & $\mathbf{4}$ \\
\hline Guidebooks and Magazines & $\mathbf{0 , 7 0 9}$ & $-0,157$ & 0,356 & $-0,106$ \\
\hline Official websites of the hotels \& destinations & $\mathbf{0 , 6 9 9}$ & 0,225 & $-0,129$ & 0,024 \\
\hline Social Network (Facebook, Twitter, etc) & $\mathbf{0 , 7 0 9}$ & 0,461 & 0,068 & 0,09 \\
\hline TravelTour_Operators & $\mathbf{0 , 6 9 2}$ & $-0,407$ & $-0,299$ & 0,062 \\
\hline Media & $\mathbf{0 , 6 9 6}$ & $-0,243$ & 0,042 & $-0,032$ \\
\hline Information_Technology & 0,324 & $\mathbf{0 , 7 2 7}$ & $-0,325$ & $-0,153$ \\
\hline Tour_Operators & 0,434 & $-0,36$ & $\mathbf{0 , 5 1 7}$ & $-0,137$ \\
\hline
\end{tabular}

Extraction Method: Principal Component Analysis. ${ }^{a}$ a. 4 components extracted.

Furthermore, based on the results extracted from the factor analysis, it can also be determined the nature of the factors itself. The item within the factor which happens to have the higher factor loading on that component determines the nature of the factor. As such, a simple factor model is shown in Figure 5, attempting to shed light on these relationships.

Figure 5: Simple structure of the factor model for the determinants of tourism demand based on a nine-item scale

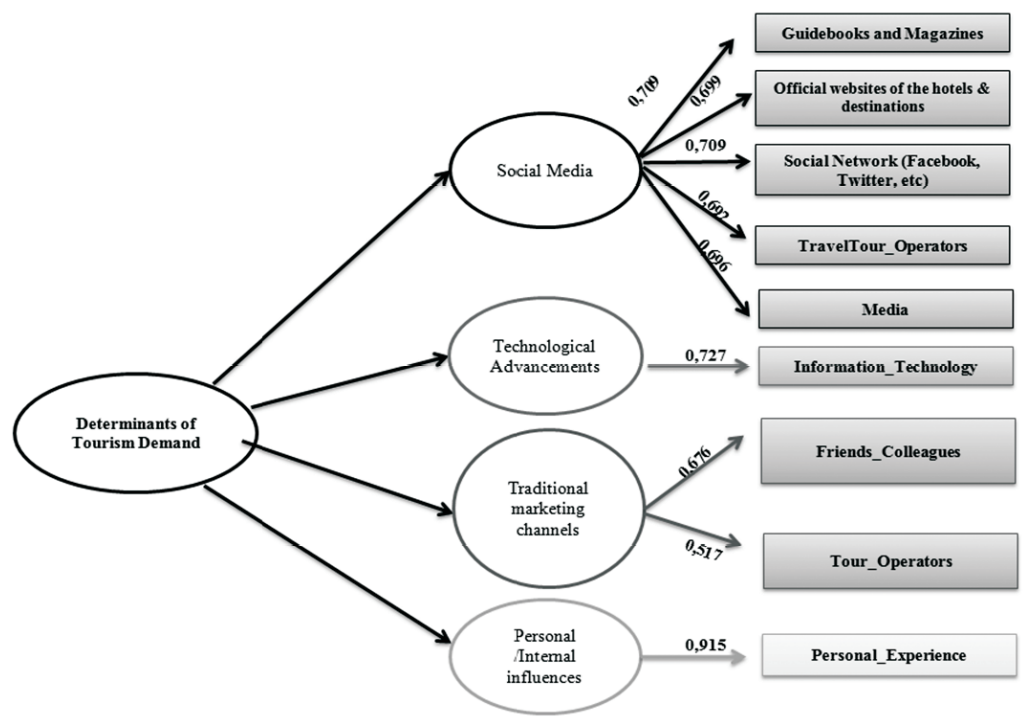

\subsection{Hypothesis Testing}

Before testing the hypothesis and describing details about the analysis technique used, let's recall our null and alternative hypothesis.

$\mathbf{H}_{\mathbf{0}}$ : Monthly Income levels of Albanian tourists and tendency to travel (measured in terms of frequency of travel) are statistically independent.

$\mathbf{H}_{1}$ : The higher the Monthly Income levels of Albanian tourists, the higher the tendency to travel (measured in terms of frequency of travel). 
A chi-square ${ }^{3)}$ analysis is conducted to test the hypothesis against the null hypothesis. This statistical test will enable us to find out whether there is an association between the two variables stated above: whether a higher level of the respondents' income level will result into a higher frequency of travel, or whether there is no difference. As it can observed from Table 6, there is about $94.3 \%$ of the sample involved in the analysis, whereas $5.7 \%$ of them just didn't answer to the question, so they were excluded from the analysis itself.

Table 6: Chi-square Test Processing Summary

\begin{tabular}{|l|c|c|c|c|c|c|}
\hline \multirow{2}{*}{} & \multicolumn{7}{|c|}{ Cases } \\
\cline { 2 - 8 } & \multicolumn{2}{|c|}{ Valid } & \multicolumn{2}{c|}{ Missing } & \multicolumn{2}{c|}{ Total } \\
\cline { 2 - 8 } & $\mathrm{N}$ & Percent & $\mathrm{N}$ & Percent & $\mathrm{N}$ & Percent \\
\hline $\begin{array}{l}\text { Monthly_Income * } \\
\text { Frequency_of_Travel_2011 }\end{array}$ & $\mathbf{1 3 3}$ & $94,30 \%$ & $\mathbf{8}$ & $5,70 \%$ & 141 & $100,00 \%$ \\
\hline
\end{tabular}

Now we can statistically check how probable that difference is due to chance, by using Pearson Chi-Square statistical value and the statistical significance of the difference observed. As it can be noticed from Table 7, which summarizes the results of the test, the difference that it is observed is statistically significant. The significance value displayed (Sig. $=.000)$ shows that it is statistically improbable that the difference has occurred by chance or due to sampling; there is less than .001 probability that the difference has occurred by chance in a sample of 133 people. So, it seems like in the actual population, respondents with higher levels of Monthly Income are more likely to travel than those with lower levels of Monthly Income.

Table 7: Chi-Square Test

\begin{tabular}{|l|c|c|c|}
\hline & Value & df & $\begin{array}{c}\text { Asymp. Sig. } \\
\text { (2-sided) }\end{array}$ \\
\hline Pearson Chi-Square & $\mathbf{1 0 2 , 5 8 1 ^ { \text { a } }}$ & 36 & $\mathbf{. 0 0 0}$ \\
\hline Likelihood Ratio & 101,064 & 36 & 0 \\
\hline Linear-by-Linear Association & 33,937 & 1 & 0 \\
\hline N of Valid Cases & $\mathbf{1 3 3}$ & & \\
\hline
\end{tabular}

To conclude, based on the following results, $\mathrm{X}^{2}(1, N=133)=102,581, \boldsymbol{p}=\mathbf{. 0 0 0}<\mathbf{0 . 0 1}$, the Null Hypothesis is rejected, and the Alternative Hypothesis is accepted (see Table 8). That is, it has been proved that the higher the Monthly Income level of the Albanian tourists, the higher the frequency of travel.

3) The formula for calculating Chi-Square is: $\boldsymbol{X}^{2}=\sum(\boldsymbol{O}-\boldsymbol{E})^{2} / \boldsymbol{E}$, where $\mathrm{O}=$ Observed frequencies; $\mathrm{E}=$ Expected frequencies. 
Table 8: Summary of Hypothesis Testing Results

\begin{tabular}{|l|c|c|c|}
\hline \multicolumn{1}{|c|}{ Null Hypothesis } & Test & Sig. & Decision \\
\hline $\begin{array}{l}\text { Monthly Income levels of Albanian tourists and } \\
\text { tendency to travel (measured in terms of frequency } \\
\text { of travel) are statistically independent. }\end{array}$ & Chi-square & $\mathbf{0 0 0}$ & $\begin{array}{c}\text { Reject the } \\
\text { Null } \\
\text { hypothesis }\end{array}$ \\
\hline
\end{tabular}

\section{Discussions and Recommendations}

Being a very complex and wide field, the recommendations for tourism managers would be addressed at a business, rather than at a governmental level. They will be directed from three different perspectives based on the results aforementioned, and especially from those drawn from the Factor Analysis. Overall what tourism managers should do is to not forget to market their companies in any most innovative and creative way possible. Because from the survey was observed that 'social networks' and 'information technology' accrued to be two among the most influential determinants of tourism buying behavior; I would recommend some key points on how tourism managers might turn this information into effective use.

One very innovative way to do this is to first make sure that the format of their company's webpage fits well on a screen of a mobile phone, because trends show that Albanian people, especially the target group we have under study uses internet on the phone at a considerable degree. As such, from 15 internet users per 100 people in 2007, in 2011 that indicator has increased to 49 internet users per 100 people (The World Bank, 2012). Living in an era where information technology prevails, it would be very disappointing and the company will probably lose a lot if someone checks the company's website and finds out it is impossible to access it through the mobile.

Another very original way of turning your company's website into a real selling platform, and yet not automated, is by implementing a live chat, where customers can actually write and get back instantaneous responses for their questions. This is a very innovative and affordable way of responding to the customer's needs and wants through the use of technology.

Moreover, tourism managers might want to be close to their potential customers with 24 hours to 7 online booking platforms. Although it might look like a considerably high budget investment at the beginning, the ROMI will pay back in a relatively short time. By providing to people this kind of user-friendly way to check for tourism products and pay for them at any time, it is more likely that it is going to influence the consumer's decision making process in the desired direction.

In addition to enhancing the role of information technology and the social media as part of their marketing strategies, tourism mangers might also want to be very careful in designing the tourism products they offer, being in harmony with the demographic profile of their target market. As such, if we relate this back to the findings, tourism managers should most probably offer tourism products for young people which are not lengthy, while approaching older people with longer holidays. One of the most important objectives of marketers is to serve different segments with products that match each segment's needs and wants. The same thing happens with tourism products, the tourism managers might want to have a tourism package for any age group, income level, education and travel career level.

And last, because tourism is a very wide and complex system, I would like to end the recommendations session with a 'one recommendation fits all' quote by Professor Philip 
Kotler, which states, "Within five years, if you run your business in the same way as you do now, you're going to be out of business” (Kotler, 2010).

\section{Conclusions}

In this paper were presented results of a quantitative study conducted on the determinants of the Albanian tourist behavior, and how this last affected the demand for tourism products. The results showed that there is a significant relationship between the monthly income level of Albanian people and their tendency to travel, otherwise measured in terms of 'frequency of travels'. In this regard, it was conducted a hypothesis testing using chi-square test. The Null hypothesis stated that the Monthly Income levels of Albanian tourists and tendency to travel (measured in terms of frequency of travel) are statistically independent. The significance value displayed from the test (Sig. $=.000$ ) shows that it is statistically improbable that the difference has occurred by chance or due to sampling; there is less than .001 probability that the difference has occurred by chance in a sample of 133 people. As a consequence the Null hypothesis is rejected and the Alternative hypothesis is accepted. Therefore, the higher is the Income level of the average Albanian tourist, the more they travel.

Furthermore, based on the research results, it has been concluded that 'Guidebooks and Magazines', 'Social Networks', 'Information Technology' and 'Personal Experience' are the determinants of which influence the most the Albanian tourists during their decision making process when it comes to purchasing tourism products.

Having studied the determinants of tourism demand from a quantitative perspective, because consumer behavior is a multidisciplinary field, it would have been of great interest to study tourism consumer behavior and tourism demand from a qualitative perspective. As such, perhaps something of interest would be to study consumer behavior as a cognitive and social phenomenon, and try to go inside what is called the 'big black box', the consumer's mind (Kotler \& Armstrong, 2010).

Furthermore, because this study is more related to Albanian tourists in relation to domestic and international tourism products, perhaps further studies should target foreign tourists visiting Albania. Results from this particular study might help tourism planners, especially at the government level, to design appropriate tourism strategies which will further help the sustainability of the development of Albania as a tourism destination.

To conclude, because this study started with the word 'change', I would also like to end it with it. In this context, I would suggest that in order to get a more comprehensive understanding of tourism consumer behavior, and how it evolves through time it is of particular value to study the same sample and variables over time. Only in this way, with a longitudinal study, 'change' in tourism consumer behavior could be properly studied and documented.

\section{References}

Andreasen, A.R. (1965). Attitudes and Consumer Behavior: A Decision Model in New Research in Marketing. ( $1^{\text {st }}$ ed). Institute of Business and Economic Research, University of California, Berkeley, p.1-61.

Alejzik, W. B. (2002a). Tourism in the face of 21st century's challenges. Institute of Physical Education Cracow, Poland.

Alejzik, W. B. (2002b). Tourism in the face of 21st century's challenges. Institute of Physical Education Cracow, Poland.

Central Intelligence Unit (2012). The World Factbook. Retrieved November, 5, 2012 from https://www.cia.gov/library/publications/the-world-factbook/geos/al.html 
Cooper, C.P., Fletcher, J., Gilbert, D. and Wanhill, S. (1993) Tourism: Principles and Practice. Pitman: London.

Crompton, J. L. (1979a). Motivations for Pleasure Vacations. Annals of Tourism Research, VI(4), p. 408- 424.

Crompton, J. L. (1979b). Motivations for Pleasure Vacations. Annals of Tourism Research, VI(4), p. 408- 424.

Cronbach, L. J. (1951). Coefficient alpha and the internal structure of tests. Psychometrika. 16, 297-334.

Bryman, A., (2008). Social research methods. 3rd ed. Oxford: Oxford University Press.

Gulid, N., Lertwannawit, A. \& Saengchan, R. (2010). Tourist Consumer Behavior and Destination Positioning for Chainat Province. p.643-651.

Grau, E. (n.d.).Using Factor Analysis and Cronbach's Alpha to Ascertain Relationships Between Questions of a Dietary Behavior Questionnaire. Mathematica Policy Research. Retrieved June 1, 2012 from http://www.amstat.org/sections/srms/proceedings/y2007/Files/JSM2007-000505.pdf

Howard J. A., Sheth J. N. (1969a). The theory of buyer Behavior. Retrieved May 16, 2012, from http://www.jagsheth.net/docs/A\%20Theory\%20of\%20Buyer\%20Behavior2.pdf. p. 467-487.

Howard J. A., Sheth J. N. (1969b). The theory of buyer Behavior. Retrieved May 16, 2012, from http://www.jagsheth.net/docs/A\%20Theory\%20of\%20Buyer\%20Behavior2.pdf. p. 467-487.

Howard J. A., Sheth J. N. (1969c). The theory of buyer Behavior. Retrieved May 16, 2012, from http://www.jagsheth.net/docs/A\%20Theory\%20of\%20Buyer\%20Behavior2.pdf. p. 467-487.

Howard J. A., Sheth J. N. (1969d). The theory of buyer Behavior. Retrieved May 16, 2012, from http://www.jagsheth.net/docs/A\%20Theory\%20of\%20Buyer\%20Behavior2.pdf. p. 467-487.

Howard J. A., Sheth J. N. (1969e). The theory of buyer Behavior. Retrieved May 16, 2012, from http://www.jagsheth.net/docs/A\%20Theory\%20of\%20Buyer\%20Behavior2.pdf. p. 467-487.

Howard J. A., Sheth J. N. (1969f). The theory of buyer Behavior. Retrieved May 16, 2012, from http://www.jagsheth.net/docs/A\%20Theory\%20of\%20Buyer\%20Behavior2.pdf. p. 467-487.

Kotler, P., Kartajaya, M. and Setiawan, I. (2010). Marketing 3.0: From Products to Customers to the Human Spirit. New Jersey: John Wiley \& Sons, Inc.

Kotler, P. \& Armstrong, G. (2010). Priciples of Marketing. 13nth ed. New Jersey, USA: Pearson Prentice Hall

Miller M. J. (n. d.). Reliability and Validity. Western International University Graduate Research Methods. Retrieved June 1, 2012 from

http://michaeljmillerphd.com/res500_lecturenotes/reliability_and_validity.pdf

Page, S. J. (2009a). Tourism Management: Managing for Change ( $3^{\text {rd }}$ ed). Burlington, USA: Elsevier.

Page, S. J. (2009b). Tourism Management: Managing for Change ( $3^{\text {rd }}$ ed). Burlington, USA: Elsevier.

Page, S. J. (2009c). Tourism Management: Managing for Change $\left(3^{\text {rd }} \mathrm{ed}\right)$. Burlington, USA: Elsevier.

Seaton, A.V. (1994). Tourism and the media, in Witt, S.J and the Miuntinho, L. (eds), Tourism Marketing and Management Handbook, Prentice-Hall.

Swarbrooke, J. \& Horner, S. (2007a). Consumer Behavior in Tourism ( ${ }^{\text {nd }}$ ed). Burlington, USA: Elsevier.

Swarbrooke, J. \& Horner, S. (2007b). Consumer Behavior in Tourism ( ${ }^{\text {nd }}$ ed). Burlington, USA: Elsevier.

Swarbrooke, J. \& Horner, S. (2007c). Consumer Behavior in Tourism ( $2^{\text {nd }}$ ed). Burlington,USA: Elsevier.

Swarbrooke, J. \& Horner, S. (2007d). Consumer Behavior in Tourism ( ${ }^{\text {nd }}$ ed). Burlington, USA: Elsevier. 
Swarbrooke, J. \& Horner, S. (2007e). Consumer Behavior in Tourism ( $2^{\text {nd }}$ ed). Burlington, USA: Elsevier.

Swarbrooke, J. \& Horner, S. (2007f). Consumer Behavior in Tourism ( $2^{\text {nd }}$ ed). Burlington, USA: Elsevier.

Swarbrooke, J. \& Horner, S. (2007g). Consumer Behavior in Tourism ( $2^{\text {nd }}$ ed). Burlington, USA: Elsevier.

Swarbrooke, J. \& Horner, S. (2007h). Consumer Behavior in Tourism ( $2^{\text {nd }}$ ed). Burlington, USA: Elsevier.

Swarbrooke, J. \& Horner, S. (2007ch). Consumer Behavior in Tourism (2 ${ }^{\text {nd }}$ ed). Burlington, USA: Elsevier.

The World Bank (2012). Internet Users (per 100 people). Retrieved November 5, 2012 from http://data.worldbank.org/indicator/IT.NET.USER.P2/countries/1W-AL?display=default

UNWTO (n.d.). Understanding Tourism: Basic Glossary. Retrieved April 15, 2012 from http://media.unwto.org/en/content/understanding-tourism-basic-glossary

Uysal, M. (1998). The Determinants of Tourism Demand: A Theoretical Perspective. In The Economic Geography of Tourism, edited by D. Ioannides and K. Debbage. London: Routledge, pp. 79-95.

Wall, G. \& Mathieson, A. (2006a). Tourism: change, impacts, and opportunities. Harlow, England, Pearson Prentice Hall.

Wall, G. \& Mathieson, A. (2006b). Tourism: change, impacts, and opportunities. Harlow, England, Pearson Prentice Hall.

World Travel \& Tourism Council - WTTC (2012). Travel \& Tourism: Economic Impact 2012 Albania. Retrieved May 03, 2012 from

http://www.wttc.org/site_media/uploads/downloads/albania2012.pdf

\section{Irisi Kasapi:}

MBA (Marketing Concentration), University of New York in Tirana in collaboration with Institut Universitaire Kurt Bösch/Switzerland, Tirana, Albania; B.S in Finance, University of New York in Tirana in collaboration with SUNY Empire State College, Tirana, Albania. She has lectured a short session of a course titled "Consumer Behavior in Albania” at undergraduate level at University of New York, Tirana. She is currently a lecturer of Management at the University 'Aleksander Moisiu', Durres, Albania. Her research interests focus on marketing and consumer behavior in the service industry, with special emphasis on tourism marketing. In addition to her academic studies, she is a professional travel agent and tour operator and manages a family business in tourism and hospitality industry. E-mail: irisikasapi@unlimitedtravel.al

Macit Koc: Ph.D. cand. (ABD) in Management \& Economics, Faculty of Management and Economics, Tomas Bata University, Czech Republic; MBA, Webster University, Missouri, USA; B.S. in Business Administration, University of Missouri - Saint Louis, USA. Mr. Koc is an experienced Lecturer, who taught in universities in Turkey, Sultanate of Oman and Kyrgyzstan. He also taught as Erasmus Exchange Scholar in Lithuania and Czech Republic. Mr. Koc has presented at international conferences and published in peer-review journals. In addition to his expertise in marketing he has a strong industry background. Mr. Koc is a professional international sales consultant and possesses considerable experience in the fields of international trade and marketing, which includes traveling to over 50 countries. His research interests focus on Sport Sponsorship and Sports Marketing. He is currently working at the final stage of writing-up his thesis titled "Sport Sponsorship as an Integrated Marketing Communication Tool. 